\title{
Christian attitude in business
}

$\mathrm{J}^{\mathrm{M}}$ Vorster $^{1}$

(Noordwes-Universiteit, Potchefstroom)

\section{ABSTRACT}

\section{Christian attitude in business}

The beginning of the twenty-first century faces new challenges in the field of business ethics. Totally new macro-ethical challenges have arisen and they have already inspired constant ethical reflection. Two major developments in the field of economics paved the way for this new interest in business ethics: the total dominance of the market driven economy and economic globalization. This article investigates the ethical challenges posed by this new environment from a Christian ethical perspective. Firstly norms are formulated flowing from the paradigm of Christian attitude as a manifestation of the attitude of Christ. These are love, stewardship, self-denial and obedience to God. These norms are then applied to the following modern-day issues in the field of business ethics: the challenge of globalization, respect for basic human rights, remuneration, the corporation as a moral model, the need for self-evaluation, political responsibility and environmental concern. In conclusion I attempt to define the role of Christians and Christian churches in transforming corporations into moral agents.

\section{INTRODUCTION}

The beginning of the twenty-first century faces new challenges in the field of business ethics. Totally new macro-ethical challenges have arisen and they have already inspired constant ethical reflection. Two major developments in the field of economics paved the way for this new interest in business ethics. Meeks (1995:118) describes the first development with his pithy statement that the market-driven economy is here to stay. State-controlled economies have failed and left behind poor countries and unstable communities. The second development is the emergence of the macro-corporation, that is, "the development of transnational corporations with their complex internal divisions of labour across national lines, their international financial structures, and their capacity to move capital

1 J M Vorster is professor of Ethics, North-West University (Potchefstroom Campus), South-Africa. 
quickly throughout the world, often rivalling governments in economic power and escaping various levels of government control" (Gunnemann 1986:68). This development is the result of the constant process of globalization.

The global companies have become major players in the field of development, political stability and the reconstruction of destabilized communities. Sound value systems for the conduct of these major players have become absolutely necessary because these companies can build or destroy communities. This process questions the notion of modernity that ethical agency should be limited to the level of individual agents propagated in the fields of social sciences and moral philosophy (Van Gerwen 2000:44). Over and against this "Kantian" approach scholars nowadays focus on a communitarian approach because corporations are perceived as institutions that act as "individuals" with corporate cultures. Ethicists are convinced that the corporation should also be a responsible moral agent because the contemporary market-driven economy raises many moral problems (see Rothchild 2005:123). To justify this persuasion one can point to the following problems among the many problems currently under discussion:

- Many scholars in the field of ethics, law and economy are concerned about the abuse of human rights by megacorporations. These abuses range from the illegal use of child labour in countries of the developing world to violations of the right of people to a clean environment. Many companies lack concern for the environment. Examples of this include the continuous fishing of whales, seals and elephant. Pollution of air and habitat is a common effect of industries. The depletion of natural resources associated with some mining activities is another cause of concern as well as the destroying of forests in the Amazon. How can these mega-corporations be held accountable? The Human Rights Commission of the United Nations monitors the human rights violations of political entities, but what about the same violations by these huge corporations?

- A further concern involves some of these corporations' lack of corporate social responsibility in spite of the growing emphasis on corporate ethics over the past few decades as Carroll (1993:34) indicates. This deficiency became evident especially in poor communities. On the one hand the market 
driven economy flourishes in areas with huge unemployment because it can then profit from low wages. Although many governments require minimum wages the competition to attract investment is so high that developing world countries are not always able to enforce these laws. On the other hand corporations can create unhealthy social divisions. Critics allege that in Nigeria, for example, oil companies have perpetuated regional and class inequalities by creating oil colonies in local areas where oil executives live lavishly in contrast to the impoverished conditions of local communities (Ike 2004:143). Another major problem is that corporations such as oil corporations can neglect their responsibility towards the ecosystem if a country has no laws in this regard. This happened in Nigeria before 1992 (Ike 2004:152).

- Mega-corporations have become very powerful. The Shell, Texaco, and Mobil Oil companies are more powerful on military or civilian levels in Nigeria today than the government of the country (Ilesamni 2004:79). Companies with such power are capable of manipulating political policies. They can use their huge investments as leverages to negotiate favourable deals irrespective of how these deals will affect the broad population. In actual fact they weaken democracies at a time when the developing world is establishing democracies after periods of oppressive regimes.

- Most countries have eased their economic regulations to such an extent that it has become easy for mega-corporations to transfer capital to other countries. The question arises: Should there be control and how?

- Another concern from an ethical perspective is the reality that certain mega-corporations are doing business with totalitarian regimes. Only in Africa many examples can be found of this deplorable conduct. One example is the way in which companies from South-Africa enable the totalitarian Mugabe regime in Zimbabwe to maintain its current policy of oppression of opponents and its abuses of human rights. Another example is the way in which the former military government of Nigeria abused human rights in order to make it possible for oil companies to commence its economic activities (Ike 2004:145). Are these companies accomplices of these actions? 
- In some instances corporations are avoiding international sanctions to further their own profits. An example of this conduct is the way in which the Hussein regime in the former Iraq was supported by some corporations to avoid the effect of sanctions. This practice lengthened the suffering of the local population because it entrenched the oppressive regime.

These moral problems compel the ethicist to ask: How can the corporations develop into responsible moral agents and what is the social responsibility of business (see Sundman 2006:1)? This question is crucial for Christian ethics today. And the Christian in business is confronted with the question: How can I do business and exploit my God-given gifts and talents and fulfil my calling to manifest the attitude of Christ in the modern corporation?

This article is an attempt to offer some answers to this question and to encourage the debate on modern business ethics from the perspective of Christian attitude flowing from the attitude of Christ. To deal with this topic the article first develops the argument that the corporation can never be value-free. Secondly the article develops a Christian ethical framework for Christians functioning within the responsible corporation and thirdly it highlights and discusses burning contemporary issues facing the corporation as a responsible moral agent within this Christian ethical framework. The purpose is to provide ethical norms that can be used in the modern corporation in its effort to become a responsible moral agent.

\section{THE CORPORATION IS VALUE-DRIVEN}

Neo-liberalism assumes value neutrality (McFague 2001:750). Rothchild (2005:138) says: "Dominant economic models envisage themselves as value-neutral enterprises that rely on expedient market mechanisms and consistently rationally self-interest choices”. This assumption in modern economics can be questioned from the premise that no corporation can claim value-neutrality. They can operate with sound values or bad values but not with no values at all. A corporation does not develop in a void. Already at its planning stage a corporation is value-driven and these values stem from the society of its birth. The corporation is deeply intertwined with other spheres of its society.

Kouwenhoven (1989:124) explains that every corporation is embedded in a certain social order with a certain value system and also in a power system which can open and close markets and which 
provides the legal framework for the corporation to function in. This is the political order. The corporation is part of a network and the interaction with other spheres of society creates the framework of values and ideals of the corporation. In a sense the corporation is the product and the reflection of the society it serves. Therefore the notion of a value-neutral corporation is invalid. A corporation is value-driven and these values can be self-centered, materialist, humanist, or service oriented. The question is thus not whether the corporation should have a value system or not, but whether the corporation has a sound value system.

Furthermore a unique variety of people are involved in the modern corporation. These are the stockholders, professional managers, entrepreneurs, employees, labourers and other stakeholders ${ }^{2}$ (Gunnemann 1986:68). All of these sectors have their own ideals for the corporation, their own expectations and their own views about the purpose of the corporation and about their own benefit. These ideals, expectations and individual values interact with the social milieu of the corporation and influence the value system.

\section{A CHRISTIAN ETHICAL FRAMEWORK FOR A RESPONSIBLE CORPORATION}

What do we mean with the concept responsible corporation? A short answer from a Christian ethical perspective is to say that a responsible corporation serves the principles of the kingdom of God. Defined more precisely it means that Christians being part of the corporation should manifest the characteristics of the Christian attitude in business on the foundation of the attitude of Christ. Christian attitude is brought to fruition in a lifestyle of love, stewardship, self-denial and obedience to God (Vorster 2004b:1).

2 According to Van Gerwen (2000:54) stakeholders include those groups which have a stake in or claim on the firm such as suppliers, customers, employees, stockholders and the local community, as well as management in its role as agent for these groups. A stakeholder is not the same as a stockholder and stakeholder responsibility is not the same as the stockholder model of corporate responsibility. In the Friedman theory managers are responsible to stockholders only while in the stakeholder theory their responsibility are more extensive.

3 I have explained the meaning of the attitude of Christ according to the New Testament in the publication referred to. 
What does this mean in the context of business ethics? This question will be argued in the next few paragraphs.

\subsection{Love}

Christian love is the cornerstone of the Christian ethical idea of social justice. Working in whatever sphere of society Christians are obliged to seek justice for all. This biblical justice is founded in the new communion with God as a result of the selfless sacrifice of Christ. However, its application is directed at the poor and the needy. Justice is concern of the poor and active involvement in the improvement of their situations (Kouwenhoven 1989:83; see also Koch 2005:281). Christians should be the conscience of people in need. Therefore, in business the primary question for Christians should be: How will the plans and prospects of a business venture influence the poor and the needy? The goodness of the business project must then be established by the answer to the question: Has it improved or worsened the position of the poor and the needy?

This principle brings to the fore many issues in the business environment. Corporations must ask questions such as: do I respect and protect basic human rights? Do I treat my workers in a humane and dignified way? Do I pay living wages? Are my policies sound, transparent and honest? Am I involved in a business that renders a useful service and adds to the development of the community at large? Do I have the effective means to deal with wrong-doings in my own sphere and am I willing to acknowledge mistakes and confess guilt and to rectify them? Many other questions can be asked in this regard, but these questions indicate how the corporation is obliged to adhere to the deed of love as a contextual expression of the attitude of Christ

\subsection{Stewardship}

Stewardship is to replace self-centered service with kingdomcentered service. In real terms it means that Christians in business should put the community first, while their own benefit is of secondary concern. Although Wiggen \& Bomann-Larsen (2004b:100) discuss the issue from another perspective their statement is applicable to Christian stewardship as well. When they say: "After all, the ultimate justification of the private sector is that it serves society at large through value creation, services, commodities, economic growth and job creation and so on”. In corporate activity the primary question should be how the intentions and actions of the 
corporation will serve the community in such a way. Will the corporation be an advantage to the community by creating jobs, prosperity and development or will only the sectors of the corporation itself benefit? Does it render a valuable service or not?

Stewardship in this world will always involve moral conflicts. The steward sometimes has to choose between bad and worse. This is especially true in the activities of corporations. Corporations will be confronted with moral risks, that is, actions of which the outcome is not clear and may have negative side-effects (Werhane 2004:106). The actions of corporations may have a double effect. This refers to the fact that actions often have more that one outcome. Actions may produce harmful side-effects (Wiggen \& Bomann-Larsen 2004a:3). A corporation has its own unique purpose and even though it is involved in the creation of wealth and the development of the community, there may sometimes be bad side-effects.

We do not speak here of actions that are intrinsically evil (mala in se) but of actions having a morally sound intention and that are done bona fide, while they nonetheless have harmful side-effects. An oil company, for example, fulfils a very important role in keeping the wheels of modern society running, but may cause suffering by polluting the environment in spite of their good intentions and sound business policies. The tobacco industry is labour intensive and creates job opportunities for many, especially in the developing countries. But smoking is dangerous and can cause a wide range of illnesses. The same is true of the pharmaceutical industry, liquor industry and arms industry. What is to be done in the case of harmful side-effects?

One approach will be just to ignore the side-effects or to maintain that the good effects outweigh the bad effects and to leave it at that. But this is not the way of true stewardship. It is morally sound to argue that while corporations should be proud and appreciative for the good they are doing, they still have the responsibility to manage the harmful side-effects in such a way that the harm is minimized as far as possible. Bomann-Larsen (2004:91) maintains that corporations should always be willing to take responsibility for harmful side-effects, even though these might be unforeseeable. If the side-effect is pollution something should be done about the pollution. Her opinion can be accommodated in the Christian value of stewardship. True stewardship means in this 
regard that the corporation should take responsibility for all its actions and do something to minimize the effects.

\subsection{Self-denial}

Neo-liberalism promotes the self-interest paradigm in economics. According to this paradigm, corporations must be driven by selfinterest. Corporations should engage in business enterprises and create wealth by making as much profits as possible. In this way the corporation acts morally responsible because good business advances everyone. Friedman (1967:133) says that "There is one and only one social responsibility of business - to use its resources and engage in activities designed to increase its profits so long as it stays within the rules of the game, which is to say, engages in open and free competition, without deception or fraud”. Therefore, doing well is doing good. Sundman (2006:7) describes this view as the "strict purpose oriented" view. This view is rightly criticized by Sen (1988:2). He contends that a corporation should firstly aim to fulfil a social role by entering into non-self-interested concerns. Sen's argument leads one to introduce the Christian ethical norm of selfdenial into the debate. In the context of business ethics the principle of self-denial will entail that Christians will be active in setting priorities in such a way that maximum profit at all costs is not the ulterior goal as proposed in the "strict purpose oriented" view. The different sectors of the corporation must sometimes be willing to sacrifice in order to serve higher ethical goals. Sundman (2006:9) defines this view as the "moral purpose oriented view". Doing good is not necessarily doing well but doing what is morally right.

In this debate a lesson can be learnt from the discussion of "good" and "success" in the ethics of Bonhoeffer (1995). Bonhoeffer wrote before and during World War II and he witnessed the tremendous development of Germany. The development of Germany in the 1930's was hailed by the population as a miraculous success story. From a very poor country after the First World War Germany became one of the economic and technological leaders in Europe. The National Socialist value system regarded any development of the German state and the nation as a success. This idea bought Bonhoeffer to the question: Can something that is successful in a material sense be regarded as morally good? He questioned this notion of his time because "when a successful figure becomes especially prominent and conspicuous, the majority gave way to the idolization of success. They become blind to right and wrong, truth 
and untruth, fair play and foul play. They have eyes only for the deed, for the successful result. The moral and intellectual faculty is blunted” (Bonhoeffer 1995:77).

Bonhoeffer (1995:78) says that this proposition is followed by another which claims to establish the conditions for the continuance of success. This is the proposition that only the good is successful. In this proposition "the competence of the critical faculty to judge success is reaffirmed. Now right remains right and wrong remains wrong. Now one no longer closes one's eyes at the crucial moment and opens it only when the deed is done. And now there is a conscious and unconscious recognition of the law of the world, a law which makes right, truth and order more stable in the long run than violence, falsehood and self-will” (Bonhoeffer 1995:78). He regards this thesis as optimistic and in the end misleading. However, I would argue that this second thesis is suitable to apply to modern business because business tends to built on the first thesis that success is the measure of all its actions. On the contrary, an action that departs from a morally good value must be regarded as successful because it serves humankind better. Thus, not: success is good, but: good is success!

In the context of business ethics today this argument entails that the success of a business does not lie ultimately in profits and other financial achievements in the first place but in the "good" the corporation has done. To achieve this "good" requires self-denial in the sense that the participant may be forced to be satisfied with less material gain. To be "good" may imply to be satisfied with lower profits and income.

A good example of such self denial can be found in the code of conduct of Levi Strauss that determined their decision to do business in China or not. According to Werhane (2004:1070) this company formulated the following provisions for engaging in Chinese business:

- All employment agreements are voluntary;

- Employees are paid fair living wages;

- Working hours are limited to no more than 60 hours per week;

- Children under 14 years of age are not hired nor allowed to work;

- There is no prison or forced labour; 
- Workers are employed on the basis of their abilities (rather than on the basis of ethnicity, gender or bias);

- Corporal punishment and mental coercion are forbidden.

Labour practices in China could not meet these requirements and as a result Levi Strauss disengaged their business in China. This disengagement meant many lost opportunities for the corporation. For example there would have been lost opportunities for inexpensive manufacturing sales to the large Chinese population to the detriment of the stockholders (Werhane 2004:109). But this was an act of self-denial - of doing good instead of doing well in the first place. Such a business is successful because of the "good" it is doing.

\subsection{Obedience}

God's work in Christ is restitution and healing. The kingdom he promises and realizes in this world is a new humanity of peace and justice. Obedience to God according to the attitude of Christ is to take an active part in this healing of the world. Seen from a Christian perspective the business corporation is also an agent of this coming kingdom. Just as Christ is focused on healing, reconciliation, development, fruition of humaneness and positive growth of the good and the beautiful, the corporation must nurture the same values and ideals. A corporation that is engaged in destruction like profiteering from a senseless war or killing God's creation by pollution is obstructing the kingdom.

Furthermore, the corporation which exploits people by dehumanizing them with misuse and inhuman wages or working hours impedes God's plan for a new humanity. Christians in business must uphold these principles in their own business conduct and should be the heralds of these principles in the business environment. Before they can be managers, investors, stockholders or other stakeholders they have to be prophets: sound and community-committed business people. An investment in a corporation must be an investment in the coming kingdom and the growth of the new humanity. A share in a business devoted to development of people is a share in God's plan of renewal for all things.

All this means that business in itself is not good or bad. It all depends on the obedience of the people involved. Their ideals, intentions, plans and conduct characterize the corporation. They 
determine, with their obedience or disobedience to God, whether the corporation is an obstructionist or an advocate of the kingdom

\section{THE CORPORATION AS A RESPONSIBLE MORAL AGENT TODAY}

In view of the norms that have been discussed here many burning ethical issues confronting the modern corporation can be identified. This article cannot deal with all of them. Therefore only a few will be discussed. The purpose of this discussion is to design ethical "keys" that can be used by Christians in business to position the corporation as a responsible moral agent in today's world. The topics under discussion are the challenge of globalization, respect for basic human rights, remuneration, the corporation as a moral model, the need for self-evaluation, political responsibility and environmental concern.

\subsection{The challenge of globalization}

Globalization and the emergence of the big corporation are changing the face of the world rapidly. The global village of today experiences the fruits of wonderful technical advances that can relay information all over the world in seconds. This process has curbed the power and abilities of national governments. In general, scholars tend to acclaim the process as a positive development. Ilesamni (2004:71) is correct in his assumption that globalization is being celebrated in many circles as a distinctive achievement of our age, drawing peoples and societies more closely together and creating far greater wealth than any previous generations knew. The argument that globalization created wealth and improved the economic conditions of many in the developed and developing worlds is beyond any doubt (Küng 1997:160).

But there is also a darker side. Close investigation reveals that the process also resulted in new forms of massive poverty and deprivation. Seen from an African perspective Ilesanmi (2004:73) argues that globalization has not only failed to produce the anticipated benefits heralded by its advocates but has in fact unleashed massive deprivation and staggering inequality on the continent. This criticism may seem harsh but the statistics provided by Ilesanmi (2004:77) force one to question the claim of "hyperglobalists" that globalization and the emergence of the big corporation carry only good news. It is worthwhile to pay closer attention to the reason for his negative assessment of globalization. 
Ilesanmi (2004:77) raises the point that alongside the phenomenal affluence that globalization is believed to have created, exists the desperate conditions of the world's poorest quarter or quintile. Roundabout 1.3 billion persons, that is, 22 percent of the world's population, live below the international poverty line. This means that their daily income has less purchasing power than one dollar had in the US in 1985 and less purchasing power than \$1.53 has in the US today. Furthermore, as a consequence of such severe poverty, 841 million persons (15 percent) are without access to health services, one billion (17 percent) are without adequate shelter, 1.3 billion (22 percent) are without access to safe drinking water, two billion (33 percent) are without electricity and 2.6 billion (43 percent) are without access to sanitation. As a further consequence of this severe poverty a quarter of all children between 5 and 14,250 million in all, are compelled to work, often under cruel conditions in mines, quarries and factories, in agriculture, construction, textile and carpet production or as domestic servants, prostitutes or soldiers. At least 120 million children between the ages of 5 and 14 work full time. Ilesanmi (2004:77) acquired this information from the United Nations Development Program (1998:49).

Globalization is therefore not only a blessing for the modern corporation, but poses a tremendous ethical challenge to the corporation as a responsible moral agent. This challenge is to help to curb the process of perennial poverty and deprivation.

Berger (1995:88) points the way with his plea for a corporation with social concern where the corporation is reshaped into a caring institution. These reshaped institutions should have a concern for human rights, the environment, the effect of its dealings on the poor (and poor countries) and the physical and spiritual well-being of its employees. In the same publication Meeks (1995:120) pleads for an alternative to the control of the world economy by multinational corporations because the increase of the GNP in expanded markets can be connected with the increase of the wealth of the rich but not with improvement of the welfare of the poor.

On the foundation of his ethical paradigm of the Trinitarian Oikonomia, according to which humankind and communities must be seen and treated as a "household", he sees the alternative in a system of relatively self-sufficient markets in relatively small regions. In these markets regional communities can organize Malteis through political and social institutions to make certain that its 
members are included in the "household". Meeks's argument can be taken further by arguing that this household can be the sphere within which the ethical principles of love, stewardship, self denial and obedience can take shape in norms for organizing the economy into a caring economy with social concern for the poor. Equal opportunities can be established where competition can take place in a just way (see Koch 2005:281). The Church can play an active part in this organization of the household and Christians can fulfil their calling to manifest the attitude of Christ in an effective way. In this way an economy "of grace" can be built as a replacement of an economy of “egoism” (Meeks 1995:125; see also Childs 2000:74).

This line of thinking contradicts the idea of the Friedman doctrine (1971:61; 1973:27 and 1976:42) that the best way to care for the poor is vigorously "profit driven" business. Making profits is only a part of the solution. Caring corporations have a wider purpose and that is not only to create wealth for some, but also to care for those not benefiting from their enterprises. But what does this mean in practical terms?

\subsection{Respect for basic human rights}

The development of a true ethos of human rights and the institution of constitutional democracies are high on the political agendas in many parts of the world - especially in the developing world. Today's society has learnt that constitutional democracy is the best political system to control abuse of power by the state and to protect the fundamental human rights of individuals and minorities. The transnational corporation sometimes obstructs this process (Kouwenhoven 1989:131). A corporation has to function in close symbiosis with the political and social order of the day.

While accepting the fact that the market-driven economy and globalization are here to stay one must go further to agree with the following statement of Ilsanmi (2004:89): "If globalization allows itself to be tamed by human rights requirements, it could produce the kind of global prosperity that its proponents have proclaimed”. Christians must promote the constant symbiosis of the corporation with the development of the ethos of human rights and the constitutional democracy.

In this respect the topic of socio-economic rights must also be addressed. Socio-economic rights are becoming an important point of discussion in the human rights debate. Proponents of the neo- 
liberal economic philosophy regard socio-economic rights as a vestige of socialism and as an obstruction to the market driven economy. This philosophy maintains that the market-driven economy will take care of the needs of the poor and the deprived if this system is allowed to function without obstacles such those involved with the quest for the realization of socio-economic rights.

This notion is not correct, at least not in every economy. With regard to South-Africa, Terreblanche has proven that this kind of economy has benefited the rich and created a bigger middle class, but the gap between the rich and the poor has actually widened. The poor are becoming poorer (Terreblanche 2003:419). Therefore the pursuance of socio-economic rights in this society is a necessity, even if their its application might affect the huge corporations. Corporations should understand this predicament and should use the noble value of self-denial as a leading principle in poor developing communities. Respect for human rights entails a respect for socioeconomic rights also.

\subsection{Remuneration}

Wages are one of three ways in which to earn money. The others are profits and interest. Adam Smith (1986:170) emphasized the importance of living wages in his classic work on the wealth of nations with his idea that "a man must always live by his work, and his wages must at least be sufficient to maintain him. Wages must even upon most occasions be somewhat more; otherwise it would be impossible for him to bring up a family” (Rothchild 2005:129). Smith's view on remuneration is deeply embedded in the great law of Christianity, namely the love of others. Friedman's (1967:161, 162) point of view is that an employer should pay to each according to what he and the instrument he owns produce. This point of view determines many of the wage policies in modern corpora-tions. This regulation seems valid but it lacks moral ground because the decision making is totally in the hands of the employer, while the needs of the employee are not taken into account. A living wage must be set, as Smith argued.

An influential campaigner of the legal institution of minimum wages in the first half of the previous century was the Roman Catholic moral theologian J A Ryan. He argued that the right to a living wage is individual, natural and absolute (Ryan 1996:161). This is a moral human right that should take concrete form in a legal 
human right. According to him the adult male labourer has a right to a wage sufficient to provide himself and his family with a decent livelihood and the adult female has the right of remuneration that will enable her to live decently as a self-supporting individual (Ryan 1996:157). Although his view on the right of the female adult in this regard is outdated, because of the modern recognition of her moral right to be treated as the equal of the male adult, his moral arguments about wages are still applicable in Christian ethics. A few of his arguments can be mentioned to demonstrate this:

- All people are equal in their inherent claims upon the bounty of nature.

- The right of access to the earth becomes concretely valid through the expenditure of useful labour.

- Those persons who are in control of the goods and opportunities of the earth are morally bound to permit access thereto on reasonable terms to all who are willing to work.

- The right to reasonable access can only be effectuated through a living wage.

- The labourer's right to a living wage is morally superior to the employer's right to interest on his capital.

- Labourers who put forth unusual efforts to make unusual sacrifices have a right to a proportionate excess over living wages, and those who are exceptionally productive or exceptionally scarce have a right to the extra compensation that goes to them under the operation of competition.

- Wages should be increased from time to time through the methods of a minimum wage by law, labour unions, profitsharing and ownership. The latter two would enable labourers to supplement their wage incomes by profits and interest and would give labourers an influential voice in the conditions of employment (see Ryan 1996:157-158).

Kouwenhoven (1989:133) introduces another important ethical norm when he argues that one of the cornerstones of a living wage is the promotion of equality. However, this does not entail equal remuneration but equal opportunities. With equal opportunities workers can compete for fair living wages by "selling” their labour without any form of prejudice or discrimination. Men should not be benefited over and against women and majorities not over and 
against minorities or citizens over and against strangers or immigrants. Koch (2005:281) argues that "Der Markt funktioniert durch Konkurrenz. Konkurrenz aber setzt Gleichheit der Konkurrenten, gleiche Chancen im Wettbewerb, voraus”. Without equality in the sense of equal opportunities, the earning of living wages is deeply inhibited.

The contributions of Ryan and Kouwenhoven provide the framework for a morally sound dealing with wages. The corporation as a sound moral agent will treat this issue according to the ethical norms described above. A corporation that exploits its labourers and profits from low wages and joblessness violates the ethic of Christian attitude.

\subsection{The corporation as a moral model}

The corporation functions in close symbiosis with the society at large. In this process the corporation influences society. Society can be a source of ethical standards which can direct the conduct of business (Carroll 1993:44). But the opposite is also true. The corporation can be a source of ethical standards that can be very influential in the society. This influence can be positive or negative.

Modern society is still the prey of large-scale corruption. This is especially true of developing countries. The regular report of Transparency International proves this point. When government and business are both corrupt, corruption becomes insurmountable. When business becomes known for usury, bribery and general corrupt business practices, the corruption spills over to all spheres of government. Government officials can entice business people to illegal and immoral practices and business people can lead government officials astray with bribery and other corrupt customs.

The calling of obedience to God obliges Christians to convince the corporation to act as a moral institution in society (Childs 1995:80). As an institution moulded together by a culture of values the corporation and the business community can exert a positive moral influence in a society where the government of the day may be corrupt. The corporation can act as a corrective to government by setting sound moral standards. Sometimes this obligation may require peaceful civil disobedience. In apartheid South-Africa the government of the day observed job reservation which meant that certain occupations were reserved for whites only. Many corporations either disinvested or just ignored this law for moral reasons. It 
is fair to say that business contributed largely to the change of the whole system and the introduction of a new constitutional democracy. In the new democracy business also became actively involved in the negotiation process and steered the new government away from old socialist ideals such as privatization and greater government control of the economy. In South-Africa business sets an example of how the corporation as a moral agent can exert a positive moral influence on society. Unfortunately there are also examples where business corrupted society and caused immense social distress. An example is the involvement of corporations in the civil war in the Congo.

\subsection{Self-evaluation}

To be a moral model in society the corporation should be willing to monitor its own actions on a regular basis in order to set and raise its own moral standards. In an ideal situation there should be adequate government codes and regulations but this is not the case, especially in developing countries. Corporations communicate their moral standards commonly in codes of conduct (Carroll 1993:45). These can function in the realm of formal policy.

Carroll (1993:53) proposes some positive steps that can be taken in the process of a corporation's self-evaluation. Consider the following among others:

- Develop codes of conduct and make them living documents;

- Provide adequate management controls so that employees will not be unnecessarily tempted;

- Carefully review goals to make sure you are not "building in" an incentive to cheat by unreasonable expectations;

- Design and use performance evaluation systems which do not overemphasize profits;

- Provide fair and reasonable reimbursement policies for business expenses.

These are common guidelines on the micro-level of business management. On the macro level a corporation can also state its position on human rights, social concern and the environment. With these noble ethical principles entrenched in codes of conduct the corporation can maintain constant soul searching to ascertain whether it is a sound moral agent. Like other moral agents such as 
people in leadership, social institutions and religious bodies the corporation can then also be a force of change for the better in societies with corrupt governments and social instability. Where society is on a high level of social stability and fairness the corporation can act in symbiosis with the other moral agents as well as the government to promote an ethos of justice in that society. In this process the corporation can operate as an example to societies still in need of such an ethos. Here the process of globalization can be a positive channel for conveying good business values from one society to another.

\subsection{Political responsibility}

As a moral model the corporation can exert positive influence in the society within which it functions. It can be an exemplary agent in a society with a morally deficient social fibre and where the government of the day does not live up to its God-given calling to promote peace and justice. The corporation can also exert pressure on the government in order to promote the necessary social changes. The changes in South-Africa over the past fifteen years and even before that were inter alia the result of corporate involvement. Business was deeply involved in the negotiations for change and for sound economic development. This country is a good example of what business can do to initiate political change for the good. It is also a good example of how the corporation can manifest its calling to stewardship in a practical and effective way.

But the corporation can also be an agent of change in another way. And that is by honouring the call for economic sanctions against corrupt dictatorial regimes when requested to do so by the international community. Sanctions often fail because big corporations see an opportunity for good business in a situation where other corporations disinvest for conscientious reasons. Was that not the case in Iraq? The peaceful process to force a change of government failed because some governments and some corporations did not honour the international call for sanctions. Eventually the result was war.

In the struggle against apartheid in South-Africa sanctions were more successful and contributed largely to the peaceful transition in the country. The United Nations (1994:29) called for an arms embargo, an oil embargo and for financial disinvestment. The Special Committee against Apartheid reported in 1989 that "sanc- 
tions had imposed substantial constraints on the South-African economy, primarily through the denial of loans and capital for investment. Estimates of the total cost imposed by economic sanctions varied significantly, but some studies had suggested that, without sanctions, South-Africa's economy could have been 20 to 35 per cent larger than it was. The oil embargo, on its own, had cost the South-African economy an estimates $\$ 22.1$ billion in the period from 1979-1988” (United Nations 1994:87). As a result of this economic sanctions in which many international corporations also played a part the moderate leadership of the country joined hands and changed an unjust system into a constitutional democracy. In this way a civil war was avoided.

A corporation can be a moral model by being an example of love, stewardship, self-denial and obedience to God. But it can also act as an efficient agent of change in a corrupt society by putting pressure on the governments to develop good structures with adequate respect for human rights.

\subsection{Environmental concern}

Huge corporations can harm the environment in many ways through their mining, harvesting, manufacturing, delivery and disposal. They are major consumers of energy and other resources, polluters of water, land and air and major producers of toxic waste and garbage. Their destructive actions regarding the environment are evident in the huge industrialized countries but even more so in the developing countries where the need for investment and development often gives them a free hand to conduct their business without restraints. They also harm the environment in another way and that is when they exploit labour by paying wages below the subsistence level, thereby contributing to the on-going cycle of poverty and environmental degradation (Vorster 2004b:260; Geisler 1989:230).

For the corporation environmental concern should therefore become just as important as social concern. As a moral agent with the intention to manifest good stewardship the corporation has to engage itself in the protection of ecosystems. This will also entail self-denial because it will often lead to change of plans, ideals, good business opportunities and lesser profits. Environmental concern is concern for the rights of future generations. All the sectors of the corporation such as employers, developers, board members, employ- 
ees and stockholders can exercise important roles in the conduct of corporations with regard to the protection of ecosystems.

The people in charge of corporations and the people benefiting from its actions are the ones that should feel responsible to find the balance between production, on the one hand, and the protection of the environment on the other. They must develop their policies and direct their investment in such a way that both development and environment are served. Every company should have the policy to conduct an environmental impact study before they begin with manufacturing, harvesting or mining. A part of their profits should be allocated to the restoration of the environment they may harm in the process of production. These are especially crucial in the developing world where governments are not fulfilling their duties to protect the environment.

\section{CONCLUSION}

Rothchild (2005:135) maintains that business should be regulated by efficient laws but he further contends that this is not the only solution to corporate corruption. Regulation should be balanced with corporate responsibility. The corporation must develop the means and the norms to monitor its own actions and to shape itself as a moral agent. A code of conduct will help to encapsulate the responsibilities of a corporation. In this regard Christian ethics have a huge responsibility towards the corporate world by contributing to processes of designing sound but also realistic moral values to assist the corporation to be a moral agent. Gunnemann (1986:69) identifies two developments that have made and can make positive steps in this direction. The one is the development of business ethics to be lectured at business schools and moulding or discussed principles into practical and realistic ethical guidelines for the responsible modern corporation.

Secondly, Christians can set a moral example by acting as responsible stock-holders and stakeholders. Gunnemann (1986:69) explains this responsibility by calling our attention to the "increased participation by churches and other eleemosynary institutions (charitable institutions such as foundations and institutions dependent on donations such as universities) in a spectrum of shareholder activities designed to monitor, modify, and correct egregious social harm done by those corporations in which they hold stock". Not only have such efforts led to changed corporate behaviour (notably in the areas 
of foreign investment in South-Africa, environmental impact, developing world marketing practices and community and employee relations) they have also contributed to legal decisions and literature clarifying the role of stockholders in the modern corporation. Stockholders and stakeholders should realize that the purpose of business is to serve people and not to make profits only. They should accept the ethical challenge to serve the society even if it will mean lower dividends and lesser benefits. Furthermore they are very able to exert a large influence on a company's strategic planning and can use these opportunities to remodel corporations to become moral agents (see Childs 2000:99).

\section{Consulted literature}

Berger, P L 1995. Vice and virtue in economic life in stackhouse, M.L. et. al. Christian social ethics in a global era. Nashville: Abingdon, 11-74.

Bomann-Larsen, L 2004. Fixing the goalposts of corporate responsibility in Wiggen, O \& Bomann-Larson, L Responsibility in world business, managing harmful side-effects of corporate activity. New York: United Nations University Press, 82-98.

Bonhoeffer, D 1995. Ethics. London: Simon \& Schuster.

Carroll, A B 1993. Business ethics within the context of Corporate Social Responsibility in Potchefstroom University for Christian Higher Education. Window on Business Ethics. Potchefstroom: Potchefstroom University for Christian Higher Education, 34-58.

Childs, J M 1995. Ethics in Business. Faith at work. Minneapolis: Fortress Press.

-, 2000. Greed. Economics and ethics in conflict. Minneapolis: Fortress Press.

Friedman, M 1967. Capitalism and freedom. Chicago: University of Chicago Press.

- 1971. A theoretical framework for monetary analysis. New York: National Bureau of Economic Research.

-, 1973. Money and economic development. The Horowitz lectures of 1972. New York: Praeger.

-, 1976. Milton Friedman in South-Africa. His visit to the Graduate School of Business University of Cape Town. March - April 1976. Cape Town: UCT.

Geisler, N L 1989. Christian ethics. Options and issues. Grand Rapids: Baker Book House.

Gunnemann, J P 1986. Business ethics in Childress. in J F \& Macquarrie, J 1986. The Westminster dictionary of Christian ethics. Philadelphia: The Westminster Press, 68-71. 
Ike, O 2004. Shell in Ogoniland in Wiggen, O \& Bomann-Larson, L Responsibility in world business, managing harmful side-effects of corporate activity. New York: United Nations University Press, 138-158.

Ilesanmi, S O 2004. Leave no poor behind: Globalization and the imperative of socio-economic and development rights from an African perspective. Journal of Religious Studies, 32(1), 71-92.

Koch, T 2005. “Gerechtig”: ein Schlagwort oder ein Grundprinzip des Rechts? Zeitschrift für Evangelische Ethik, 49(4), 278-283.

Kouwenhoven, A 1989. Inleiding in de economishe ethiek. Nijkerk: Callenbach.

Küng, H 1997. A global ethic for global politics and economics. London: SCM Press.

McFague, S 2001. Life abundant: Rethinking Theology and economy for a planet in peril. Minneapolis: Fortress Press.

Meeks, M D 1995. God's Oikonomia and the New World economy in stackhouse, M L et. al. Christian social ethics in a global era. Nashville: Abingdon, 111-126.

Rothchild, J 2005. Ethics, law, and economics: Legal regulation of corporate responsibility. Journal of the Society of Christian Ethics 25(1), 123-146. 2005.

Ryan, J A 1996. Economic Justica. Selections from Distributive Justice and A Living Wage (edited by H R Beckley), Westminster: John Knox Press.

Sen, A 1988. On ethics and economics. Oxford: Blackwell.

Smith, A 1986. The wealth of the nations. London: Penguin Books.

Sundman, P 2006. The business corporation: A morally responsible agent. presentation at the annual International Conference of the Society of Christian Ethics, Phoenix, Arizona, US, 5-8 January, 2006 (Copy in possession of the author).

Terreblanche, S 2003. A history of inequality. Pietermaritzburg: University of Natal Press.

United Nations, 1994. The United nations and Apartheid 1948-1994. New York: United Nations.

United Nations, United Nations Development Program (UNDP). New York: Oxford University Press.

Van Gerwen, J 2000. Corporate culture and ethics in Verstraeten, J. Business Ethics. Broadening the perspectives. Leuven: Peeters, 43-78.

Vorster, J M 2004a. The attitude of Christ as a principle for modern Christian ethics seen from a classic Reformed perspective. Studia Historiae Ecclesiasticae XXX(2):1-28.

-, 2004b. Ethical perspectives on human rights. Potchefstroom: Potchefstroom Theological Publications. 
Werhane, P H 2004. The principle of moral effect and moral risk: Some casestudies of US transnational corporations in Wiggen, O \& Bomann-Larson, L Responsibility in world business, managing harmful side-effects of corporate activity. New York: United Nations University Press, 105-120.

Wiggen \& Bomann-Larsen, 2004a. Addressing side-effect harm in the business context: Conceptual and practical challenges in Wiggen, O \& BomannLarson, L. Responsibility in world business, managing harmful side-effects of corporate activity. New York: United Nations University Press, 3-13.

-, 2004b. The principle of double-effect, revised for the business context in Wiggen, O \& Bomann-Larson, L. Responsibility in world business, managing harmful side-effects of corporate activity. New York: United Nations University Press, 99-101. 